\title{
Upaya Peningkatan Aktivitas Belajar mahasiswa Melalui Lesson Study Matakuliah Dasar Teknik Digital
}

\author{
Ilmiyati Rahmy Jasril ${ }^{*}$ \\ ${ }^{1}$ Program Studi Pendidikan Teknik Elektronika, Fakultas Teknik, Universitas Negeri Padang \\ *Corresponding author, e-mail: ilmiyatirahmyjasril@ft.unp.ac.id
}

\begin{abstract}
Abstrak- Penelitian ini bertujuan untuk mendeskripsikan aktivitas belajar mahasiswa dalam Mata Kuliah Dasar Teknik Digital melalui lesson study. Penelitian ini merupakan penelitian action research. Metode penelitian mengikuti tahap Plan, Do dan See pada lesson study yang dilakukan sebanyak dua siklus. Refleksi yang dilakukan dosen model secara kolaborasi dengan observer sebagai acuan untuk perbaikan pembelajaran. Pelaksanaan lesson study dapat memberikan dampak positif bagi aktivitas mahasiswa pada proses pembelajaran diantaranya berpikir bersama, bertanya, menjawab, kerjasama, aktif berdiskusi, pengambilan keputusan, menerapkan dan menganalisis persamaan maupun rangkaian dalam pembelajaran Dasar Teknik Digital.
\end{abstract}

Kata Kunci : Lesson Study, Aktivitas Mahasiswa, dan Dasar Teknik Digital

\begin{abstract}
This study aims to describe the learning activities of students in Digital Engineering Basic Subjects through lesson study. This research is an action research study. The research method follows the Plan, Do and See stages in the lesson study which is conducted in two cycles. The reflection made by the model lecturer in collaboration with the observer as a reference for learning improvement. The implementation of lesson studies can have a positive impact on student activities in the learning process including thinking together, asking questions, answering, collaborating, actively discussing, making decisions, applying and analyzing equations and circuits in learning Digital Techniques.
\end{abstract}

Keywords : Lesson Study, Student Activities and Basic Digital Engineering

This is an open access article distributed under the Creative Commons 4.0 Attribution License

\section{Pendahuluan}

Perguruan Tinggi merupakan jenjang pendidikan tinggi, dimana dosen berperan sebagai fasilitator pada proses pembelajaran. Pembelajaran saat ini telah berpusat kepada peserta didik dan tidak lagi berpusat pada pendidik. Sebagai salah satu output pembelajaran, mahasiswa diharapkan memiliki keterampilan abad 21, agar mampu berkompetisi dan unggul pada bidang keahliannya. Apalagi dunia kerja sangat membutuhkan orangorang yang memiliki keterampilan berpikir tingkat tinggi (higher-order thingking skills). Adapun keterampilan abad 21 adalah memadukan teknologi informasi dan komunikasi yang telah mengubah cara belajar, sifat pekerjaan yang dapat dilakukan, dan makna hubungan sosial [1].

Dosen sebagai pendidik juga diharapkan memiliki sembilan prinsip untuk mengajarkan keterampilan abad ke-21 yaitu: (1) membuat kurikulum pembelajaran relevan dengan big picture; (2) disiplin dalam mengajar; (3) mengembangkan kemampuan berpikir yang lebih rendah dan lebih tinggi untuk mendorong pemahaman dalam konteks yang berbeda; (4) mendorong transfer pembelajaran; membelajarkan bagaimana 'belajar untuk belajar' atau metakognisi; (6) memperbaiki kesalahpahaman secara langsung; (7) menggalakkan kerja sama tim; (8) memanfaatkan teknologi untuk mendukung pembelajaran; dan (9) meningkatkan kreativitas mahasiswa [2]. Pada pembelajaran saat ini mahasiswa diharapkan tidak lagi mengedepankan sikap individual melainkan bersikap terbuka dan bekerjasama dengan teman sejawat. Pengambilan keputusan bersama, berbagi informasi, bekerjasama, berinovasi, dan kecepatan bekerja menjadi aspek yang sangat penting pada saat ini.

Manusia adalah makhluk sosial yang tidak bisa 
berdiri sendiri dalam melakukan setiap aktivitasnya. Manusia selalu membutuhkan kerja sama dengan orang lain. Begitu juga dengan mahasiswa dalam proses pembelajaran membutuhkan rekan sejawat untuk saling bertukar pikiran, berpikir bersama, dan komunikatif untuk mencapai tujuan pembelajaran. Dalam hal ini perlu adanya pembelajaran yang menyenangkan, menarik, komunikatif, dan kooperatif. Pembelajaran merupakan perpaduan dari dua aktivitas, yaitu aktivitas mengajar dan aktivitas belajar [3]. Aktivitas mengajar seorang dosen memberikan peranan dalam konteks mengupayakan terciptanya jalinan komunikasi harmonis antara dosen itu sendiri dengan mahasiswanya.

Aktivitas belajar mahasiswa di kelas dapat menunjukkan berbagai perilaku yang beragam. Salah satu yang mendukung mahasiswa untuk meningkatkan pemahaman dan kreatifitas adalah aktifitas mahasiswa yang dilakukan pada saat proses pembelajaran [4]. Jenis-jenis aktifitas mahasiswa dalam belajar yang dikemukakan [4], [5] yaitu 1) Visual activities, yang termasuk di dalamnya membaca, memperhatikan gambar demonstrasi, percobaan, pekerjaan orang lain; 2) Oral activities, misalnya menyatakan, merumuskan, bertanya, memberi saran, mengeluarkan pendapat, mengadakan wawancara, diskusi; 3) Listening activities, sebagai contoh mendengarkan: percakapan, diskusi, musik, pidato. 4) Writing activities, seperti menulis cerita, karangan, laporan, angket, menyalin; 5) Drawing activities, misalnya menggambar, membuat grafik, peta, diagram; 6) Motor activities, yang termasuk didalamnya antara lain: melakukan percobaan, membuat konstruksi, bermain; 7) Mental activities, sebagai contoh misalnya: menanggapi, mengingat, memecahkan soal, menganalisa, mengambil keputusan; 8) Emotional activities, seperti: menaruh minat, merasa bosan, gembira, bersemangat, bergairah, tenang.

Observasi yang dilakukan terhadap aktivitas mahasiswa pada Mata Kuliah Dasar Teknik Digital Offering PTI18C pada kegiatan Program Magang Dosen RISTEKDIKTI tahun 2018 di Universitas Negeri Malang (UM), mahasiswa menunjukkan aktivitas-aktivitas belajar yakni: (1) mahasiswa kurang aktif dalam merespon pertanyaan dari dosen; (2) beberapa mahasiswa kurang antusias, tidak tertarik belajar, mengantuk dan mengobrol dengan teman sejawat disebelahnya saat dosen memberikan penjelasan; (3) mahasiswa belum aktif berdiskusi dan berinteraksi dengan rekan sejawat saat dosen memberikan suatu topik permasalahan yang dipelajari; (4) Perkuliahan dimulai dari jam ke 5-8 dan sehingga terlihat mahasiswa kurang fokus dalam pembelajaran. Dengan indikasi ini perlu adanya proses pembelajaran yang memicu aktivitas mahasiswa agar aktif, antusias, dan dapat bekerjasama/kolaboratif dalam upaya menciptakan mahasiswa yang memiliki keterampilan abad 21 . Berbagai usaha yang dapat dilakukan dosen sebagai fasilitator/mediator pembelajaran untuk mencapai tujuan pembelajaran dalam meningkatkan pemahaman mahasiswa terhadap materi yang dipelajari agar mahasiswa terlibat aktif dalam pembelajaran.

Untuk menumbuhkan aktivitas kolaboratif mahasiswa dalam pembelajaran salah satunya melalui pembelajaran kooperatif. Pembelajaran kooperatif (Cooperative Learning) merupakan strategi pengajaran yang dirancang untuk mendidik mahasiswa dalam bekerja sama kelompok dan interaksi antar mahasiswa [6]. Metode pembelajaran kooperatif dapat: (a) mengajarkan mahasiswa menjadi percaya kepada dosen; (b) kemampuan berpikir; (c) mencari informasi dari sumber lain dan belajar dari mahasiswa lain; (d) mendorong mahasiswa untuk mengungkapkan idenya secara verbal dan membandingkan dengan ide temannya; (e) membantu mahasiswa untuk belajar saling menghormati mahasiswa yang pintar dan mahasiswa yang kurang serta dapat menerima perbedaan tersebut. Pembelajaran kooperatif bertujuan untuk meningkatkan pemahaman mahasiswa terhadap materi yang dipelajari dan dapat melatih mahasiswa untuk mempunyai kemampuan sosial seperti bekerjasama, saling memahami, saling berbagi informasi, saling membantu antar teman kelompok, dan bertanggungjawab terhadap sesama teman kelompok untuk mencapai tujuan umum kelompok.

Lesson study merupakan salah satu upaya untuk meningkatkan proses dan hasil pembelajaran yang dilaksanakan secara kolaboratif dan berkelanjutan oleh sekelompok dosen [7]. Penerapan lesson study sekarang ini tidak hanya dapat diterapkan di sekolah-sekolah seperti awalnya di Jepang. Namun penerapan lesson study telah diterapkan di beberapa universitas di Indonesia. Lesson study telah diterapkan tiga universitas yaitu Universitas Pendidikan Indonesia (UPI) di Bandung, Universitas Negeri Yogyakarta (UNY) di Yogyakarta, dan Universitas Negeri Malang (UM) di Malang bekerjasama dengan JICA (Japan International Cooperation Agency) mengimplementasikan IMSTEP (Indonesia Mathematics and Science Teacher Education 
Project) yang bertujuan untuk meningkatkan kualitas pendidikan Matematika dan Ilmu Pengetahuan Alam di Indonesia [8]. Implementasi Lesson study secara signifikan dapat meningkatkan kompetensi pengajar di tiga Perguruan Tinggi tersebut.

Lesson study adalah suatu pendekatan peningkatan kualitas pembelajaran yang awal mulanya berasal dari jepang yang dikenal dengan istilah "jugyokenkyu". Lesson study merupakan suatu model pembinaan profesi pendidikan melalui pengkajian pembelajaran secara kolaboratif dan berkelanjutan berlandaskan prinsip kolegialitas dan mutual learning untuk membangun learning community. Jadi, Lesson Study adalah sebuah cara atau sistem untuk mengembangkan kemampuan dosen secara kolaboratif guna memperbaiki kualitas pembelajaran/pendidikan. Penelitian Tindakan Kelas (PTK) berbasis lesson study adalah model dalam membelajarkan mahasiswa lebih baik dengan mengidentifikasi masalah pembelajaran, memilih pemecahan masalah tertentu di antara berbagai alternatif tindakan yang dapat digunakan untuk memecahkan masalah pembelajaran tersebut, dan di dalam melaksanakan tindakan tersebut, dalam setiap pertemuan siklus lesson study yaitu Plan, Do, dan See.

Lesson study merupakan satu siklus yang dimulai dengan pembentukan kelompok Lesson study (dalam masyarakat belajar professional) yang disebut tim LS dengan tahapan yaitu perencanaan (Plan), pelaksanaan (Do), dan melihat kembali atau refleksi (See) [9], [10]. lesson study memberikan banyak peluang bagi dosen untuk berkolaborasi dengan teman sejawat agar dapat merubah perspektif dosen tentang pembelajaran dan belajar untuk melihat proses pembelajaran yang dilakukan dosen dari perspektif mahasiswa [11]. Tahap Plan: merencanakan pelaksanaan pembelajaran (skenario) berdasarkan kondisi kelas dan fokus kompetensi yang ingin dicapai secara kolaboratif seperti skenario (RPP) dan perangkat Lembar Kerja mahasiswa (LKM), media, sumber belajar dan instrumen. Tahap Do: melaksanakan pembelajaran oleh "dosen model" dengan skenario yang telah dikembangkan bersama.

Di tahap Do ini, Tim LS melakukan observasi pembelajaran yang difokuskan kepada aktivitas belajar mahasiswa, dan merekam fakta/fenomena belajar yang menarik (kapan mahasiswa konsentrasi, kapan tidak konsentrasi, interaksi mahasiswa-mahasiswa-dosen-media) dan mengobservasi hal-hal lain yang menjadi fokus masalah yang ingin dipecahkan PTK. Tahap see: melakukan refleksi melalui kegiatan diskusi (secara formal, dipimpin moderator). Adapun di tahap see ini, refleksi diri dosen model, komentar semua pengamat (fokus pada aktivitas belajar mahasiswa, sedikit tentang langkah dosen), komentar pengamat ahli (pakar) jika ada (dosen, pengawas, KS, widyaiswara). Ketiga tahapan tersebut dilakukan secara berulang (Siklus). Siklus berikutnya, dilakukan tergantung waktu dan kebutuhan.

Lesson study diharapkan dapat secara efektif untuk meningkatkan aktivitas mahasiswa dan memperbaiki kualitas mengajar dosen dalam pembelajaran Dasar Teknik Digital. Sehingga mahasiswa lebih interaktif dalam kegiatan pembelajaran.

\section{Metode Penelitian}

. Penelitian ini merupakan penelitian action research. Penelitian ini dilakukan melalui tahapantahapan lesson study. Kegiatan lesson study yang dilakukan melalui tahap Plan (perencanaan), Do (pelaksanaan) dan see (refleksi) akan dijelaskan melalui data deskriptif menggunakan lembar observasi dan dokumentasi. Adapun hal yang dijelaskan adalah bentuk pelaksanaan pembelajaran yang dilakukan dosen model dan aktivitas mahasiswa. Aktivitas mahasiswa merupakan dampak dari pelaksanaan pembelajaran yang telah direncanakan dan direfleksi dalam kegiatan lesson study. Penelitin ini melibatkan peneliti (dosen model), 3 orang observer pada siklus 1 dan 4 orang observer pada siklus 2 sebagai tim lesson study yang membantu kegiatan. Lesson study dilakukan pada mahasiswa Prodi PTI18C Jurusan Teknik Elektro Universitas Negeri Malang pada Mata Kuliah Dasar Teknik Digital.

Lesson study yang dilakukan secara kolaboratif antara dosen model dan observer dalam perencanaan, pelaksanaan dan refleksi adalah upaya peningkatan aktivitas belajar mahasiswa dalam kegiatan pembelajaran. Penelitian yang dilakukan menggunakan siklus sesuai dengan kegiatan lesson study yaitu plan, do, dan see yang dilakukan sebanyak dua siklus dengan materi yang berbeda. Satu siklus terdiri dari satu kali pertemuan. Teknik pengumpulan data yaitu dengan lembar observasi dan dokumentasi.

\section{HASIl DAN PEMbahaSAN}

Pada siklus 1, tahap Plan dilakukan oleh peneliti dan 3 orang observer. Dalam kegiatan tersebut peneliti sebagai dosen model telah membuat rancangan pembelajaran tentang media pembelajaran dan model pembelajaran yang dipilih 
adalah Pendekatan Struktural (PS) jenis struktur Number-Heads-Together (NHT). Pendekatan Struktur NHT sering disebut berpikir secara berkelompok adalah suatu pendekatan yang digunakan untuk melibatkan mahasiswa dalam menelaah materi yang tercakup dalam suatu pelajaran dan mengecek pemahaman mereka terhadap isi pelajaran tersebut. Dosen model memilih pendekatan struktur NHT ini karena materi pembelajaran memungkinkan mahasiswa untuk berlatih lebih banyak melakukan latihan untuk meningkatkan pemahaman materi dan keaktifan mahasiswa di kelas. Pada tahap Plan ini dosen model menjelaskan juga bagaimana kondisi kelas dan jadwal perkuliahan yang mendekati istirahat siang. Waktu tersebut adalah dimana mahasiswa sulit untuk fokus dan disiplin untuk mendengarkan arahan dari dosen model.

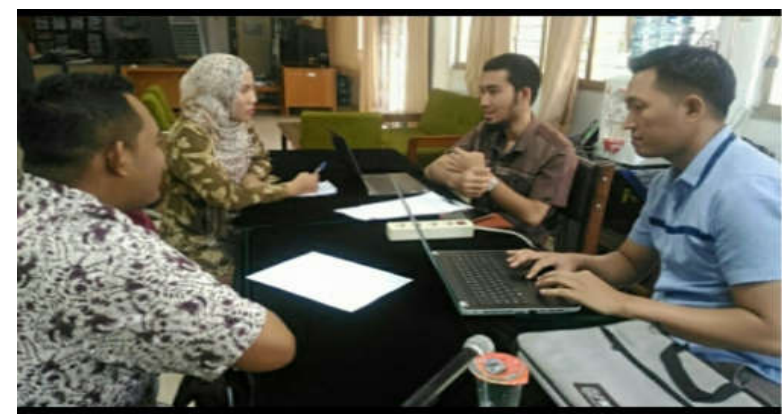

Gambar 1. Tahap Plan Siklus 1

Tahap Do adalah tahap pelaksanaan dari lesson study. Tahap ini diamati oleh 3 orang observer. Dosen model memulai perkuliahan dengan memberi salam, dosen model memperkenalkan diri, salah satu mahasiswa memimpin doa, dosen mengecek kehadiran mahasiswa, dosen dan mahasiswa mengaitkan kompetensi yang telah dipelajari dan dikembangkan sebelumnya dengan kompetensi yang akan dipelajari, dosen menginformasikan tujuan pembelajaran, dosen menyampaikan garis besar cakupan materi kegiatan yang akan dilakukan.

Pada kegiatan inti dosen model mengelompokkan mahasiswa menjadi 7 kelompok yang beranggotakan 3-4 orang. Setiap kelompok diberi penomoran. Kelompok yang telah dibentuk diberi inisial A-G. Dosen membagikan lembar kerja mahasiswa (LKM) kepada mahasiswa. Untuk latihan 1 pada LKM, dosen mengajukan pertanyaan dengan menampilkan gambar pada slide power point yang ditampilkan seperti gambar 2 berikut ini.

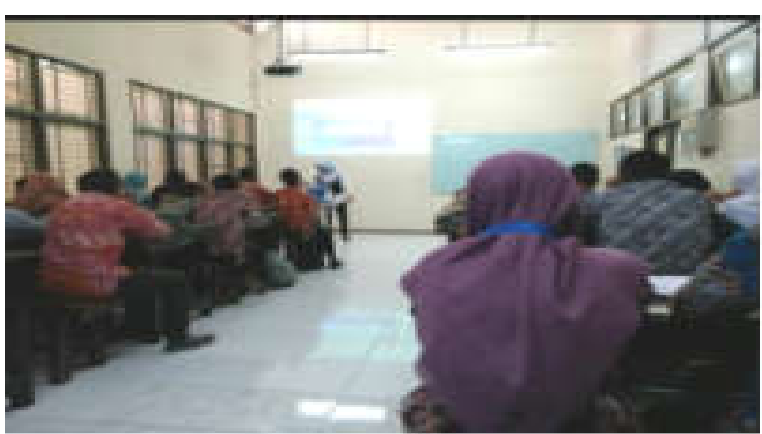

Gambar 2. Kegiatan Do Siklus 1 Pembentukan Kelompok dan Pembagian LKM

Selanjutnya mahasiswa menyatukan pendapat terhadap jawaban pertanyaan dan menyakinan tiap anggota dalam tim mengetahui jawaban tersebut seperti gambar 3 . berikut ini.

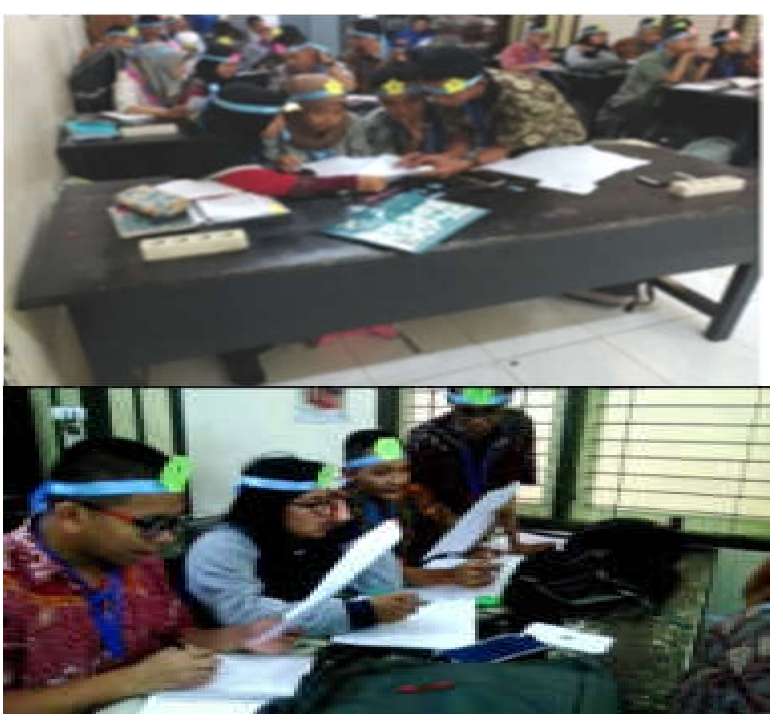

Gambar 3. Kegiatan Do Menyatukan Pendapat

Berdasarkan hasil temuan penelitian yang dilakukan oleh [12] bahwa aktivitas kerjasama mahasiswa yang mendukung pembelajaran kooperatif akan nampak setelah dilakukan perbaikan pembelajaran melalui lesson study yaitu antusiasme mahasiswa dalam bekerja sama, mahasiswa fokus berdiskusi dengan kelompoknya sendiri, dominasi mahasiswa dalam kelompok menurun, mahasiswa memanfaatkan waktu secara maksimal. Kerjasama yang dilakukan mahasiswa dalam kegiatan kelompok agar mahasiswa saling membantu dalam mengerjakan tugas sehingga hasil yang didapat lebih maksimal.

Mahasiswa menulis jawaban pada LKM. Dosen memanggil mahasiswa yang nomor initial tertentu, kemudian mahasiswa yang nomornya sesuai mengacungkan tangan dan menjawab pertanyaan untuk seluruh mahasiswa di depan kelas. Perlakuan 
yang sama juga dilakukan pada latihan 2, tetapi setelah latihan 2 selesai dilaksanakan, dosen model menampilkan video ice breaking dan mahasiswa pun antuasias mengikuti gerakan yang ditampilkan video tersebut seperti gambar 4 berikut ini.

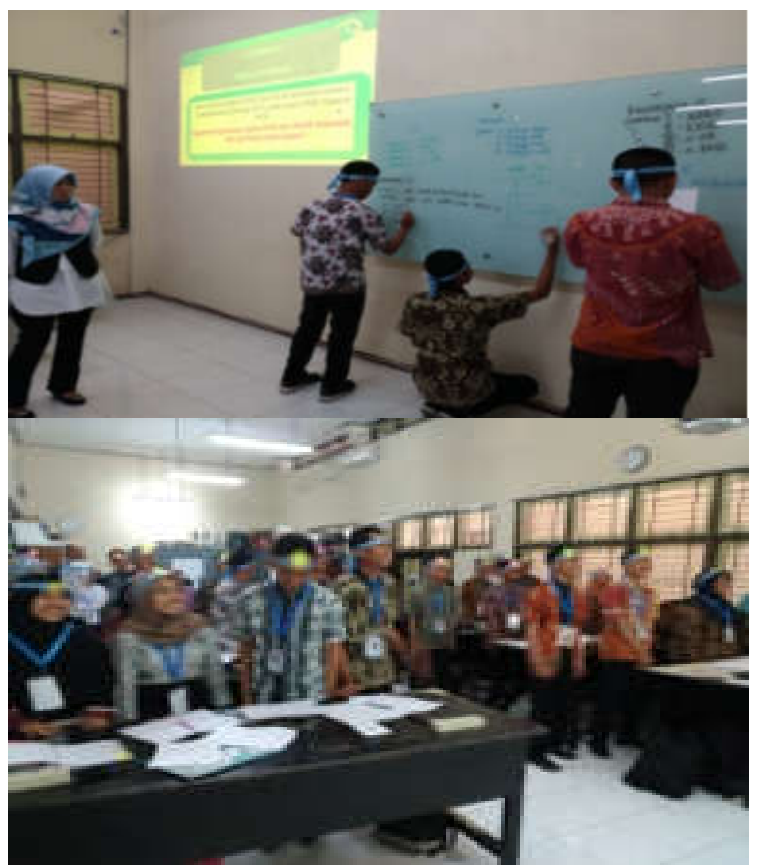

Gambar 4. Kegiatan Do Tampil Ke Depan dan Ice Breaking

Pemberian Ice breaking bertujuan untuk mengembalikan kefokusan mahasiswa untuk tertarik belajar. Ada beberapa manfaat melakukan aktivitas ice breaking menurut [13] diantaranya adalah: Menghilangkan kebosanan, kejemuan, kecemasan, dan keletihan karena bisa keluar sementara dari rutinitas pelajaran dengan melakukan aktivitas gerak bebas dan ceria. Aktivitas yang ditunjukkan mahasiswa setelah pemberian Ice breaking yaitu (a.) Melatih berpikir secara kreatif dan luas mahasiswa; (b.) Mengembangkan dan mengoptimalkan otak dan kreativitas mahasiswa; (c.) Melatih mahasiswa berinteraksi dalam kelompok dan bekerja sama dalam satu tim; (d.) Melatih berpikir sistimatis dan kreatif untuk memecahkan masalah; (e.) Meningkatkan rasa percaya diri; (f.) Melatih menentukan strategi secara matang; (g.) Melatih kreativitas dengan bahan yang terbatas; (h.) Melatih konsentrasi, berani bertindak dan tidak takut salah; (i.) Merekatkan hubungan interpersonal yang renggang; (j.) Melatih untuk menghargai orang lain; (k.) Memantapkan konsep diri; (1.) Melatih jiwa kepemimpinan; (m.) Melatih bersikap ilmiah; (n.) Melatih mengambil keputusan dan tindakan.
Terlihat mahasiswa aktif untuk melaksanakan diskusi, bekerjasama, saling berinteraksi dengan teman sejawatnya, aktif bertanya dan memberikan pendapat untuk menyelesaikan latihan-latihan yang diberikan dosen. mahasiswa dapat melakukan penyederhanaan ekpresi Aljabar Boolean dan menggambarkan rangkaian. Dari uraian di atas, maka ice breaking dapat dijadikan sebagai solusi untuk memecahkan masalah yang disebabkan faktor non akademik, serta untuk meningkatkan pencapaian tujuan pengiring, serta optimalisasi pencapaian tujuan pembelajaran.

Dosen melanjutkan penjelasan materi dan beserta contoh soal. Pada latihan 3, dosen model memberikan reward terhadap kelompok yang berhasil menjawab pertanyaan yang diajukan dosen pada latihan 3. Kegiatan penutup, dosen dan mahasiswa bersama-sama membuat kesimpulan mengenai materi pembelajaran, menyampaikan tugas dari materi yang telah di bahas, mahasiswa mengungkapkan kesan dan manfaat pembelajaran yang telah dilaksanakan, dosen menutup pembelajaran dengan doa bersama dan memberi salam.

Adapun nilai-nilai aktivitas dalam pembelajaran dikemukakan oleh [4] yaitu: a) para mahasiswa mencari pengalaman sendiri dan langsung mengalami sendiri, b) beraktifitas sendiri akan mengembangkan seluruh aspek pribadi mahasiswa secara integral, c) memupuk kerja sama yang harmonis dikalangan mahasiswa, d) para mahasiswa bekerja menurut minat dan kemampuan sendiri, e) pelajaran disekolah menjadi hidup sebagaimana aktivitas dalam kehidupan masyarakat.

Tahap refleksi, dosen model dan observer membahas mengenai aktivitas mahasiswa setelah pembelajaran dan di dapatkan lesson learn yaitu pembelajaran berkelompok dapat dibentuk oleh mahasiswa sendiri atau dosen. Tetapi dalam penerapan lesson study ini, kelompok dibentuk oleh dosen. Pembelajaran kelompok menurut [14] "kelompok dapat dibentuk oleh mahasiswa sendiri atau oleh guru. Mereka dapat secara acak atau sengaja dibentuk dan mungkin homogeneous (anggota kelompok memiliki kemampuan yang sama) atau heterogen dalam posisi".

Group dalam pembelajaran dapat berfungsi sebagai: 1) lingkungan sosiologis yang menyenangkan; 2) Anggota kelompok bekerja secara paralel satu sama lain, pada masalah yang sama, tetapi pendekatan, metode, dan hasil mereka selalu didiskusikan, dinegosiasikan, dan diperiksa untuk mencapai kesepakatan; 3) masalahnya dibagi menjadi sub-masalah dan didistribusikan ke (atau 
oleh) anggota kelompok sedemikian rupa sehingga setiap anggota kelompok bertanggung jawab untuk bagian tertentu, dan jawaban lengkap untuk masalah terdiri dari kontribusi individu. Tidak semua proses pembelajaran dapat dilakukan secara berkelompok. Namun, aktivitas pembelajaran secara berkelompok berperan penting untuk beberapa proses belajar untuk memberikan stimulasi kepada mahasiswa. Ketepatan waktu dari hasil pembahasan kasus-kasus atau permasalahan yang diberikan dosen sangat bergantung pada keaktifan dan kerjasama setiap anggota kelompok tersebut. Jika hanya satu mahasiswa yang gagal, pekerjaan tidak akan selesai tepat waktu. Secara tidak langsung mahasiswa harus bertanggung jawab dalam menyelesaikan permasalahan yang menjadi topik pembahasan.

Observer mengungkapkan aktivitas kelompok yang terlihat pada proses pembelajaran seperti salah satu anggota kelompok E menunjukkan mampu bekerjasama, membantu teman yang kurang dalam pemahaman, mempunyai inisiatif untuk bertanya kepada kelompok lain jika pada kelompokknya tidak dapat menemukan pemecahan masalah yang sedang dibahas atau mengajukan pertanyaan kepada dosen sehingga dosen dapat memberikan bimbingan secara intensif. Pemberian reward oleh dosen model mampu meningkatkan semangat mahasiswa untuk aktif dalam menjawab soal. Anggota kelompok E4 mampu melibatkan anggota lain dalam diskusi. Ice breaking mampu mengkondisikan mahasiswa yang mulai jenuh untuk antusias dan fokus belajar kembali. Pendekatan pembelajaran yang digunakan dosen model dirasa cukup menarik dan mudah untuk diamati. Ice breaking mampu mengembalikan konsentrasi mahasiswa (kemampuan dosen dalam melihat kondisi mahasiswa sangat baik). Anggota kelompok A di menit terakhir cukup aktif dibandingkan dengan awal-awal pembelajaran yang cenderung pasif.

Pemberian latihan-latihan berkelanjutan untuk setiap materi selalu diberikan agar menambah pemahaman dan meningkatkan aktivitas mahasiswa dalam pembelajaran berkelompok. Pembagian kelompok heterogen mampu meningkatkan keaktifan mahasiswa dalam belajar. Pemberian reward mampu merangsang mahasiswa untuk aktif. Pada saat pembelajaran berkelompok mahasiswa menjadi aktif mengerjakan LKM. Ada diskusi dalam kelompok dan bahkan diskusi antar kelompok. Namun ada mahasiswa kurang aktif, observer memberikan masukan untuk pertemuan pada siklus berikutnya untuk membuat perubahan posisi duduk mahasiswa yang kurang aktif dan tidak fokus belajar dapat menjadi aktif dalam pembelajaran.

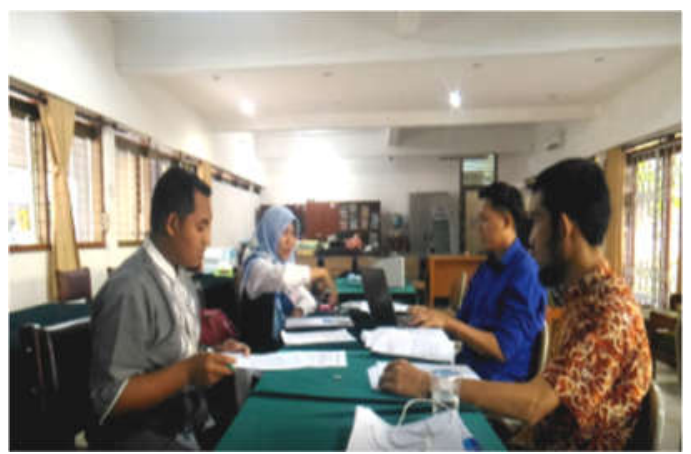

Gambar 5. Tahap See Siklus 1

Selanjutnya pada siklus 2, dilakukan untuk memperbaiki pembelajaran sehingga aktivitas belajar mahasiswa diharapkan adanya peningkatan pembelajaran dari sebelumnya. Pada tahap Plan di siklus 2 ini, dilakukan oleh tim lesson study setelah dilakukan tahap see pada siklus 1. Pada tahap plan ini dosen model menjelaskan juga bagaimana perubahan skenario dari pertemuan sebelumnya. Bedasarkan refleksi dari pertemuan sebelumnya, dosen memperbaiki beberapa skenario meliputi cara penghitungan penomoran kelompok dimulai dari belakang sehingga beberapa mahasiswa yang tidak fokus dan belum dapat mengikuti proses pembelajaran dengan baik dapat aktif pada pertemuan ini. Pada pertemuan ini diberikan kuis untuk mengecek pemahaman mahasiswa diakhir proses pembelajaran dengan memberikan batasan waktu penyelesaian yang telah ditentukan dengan tujuan agar kelompok-kelompok yang belum aktif dapat aktif pada perkuliahan ini.

Dalam kegiatan tersebut peneliti sebagai dosen model telah membuat rancangan pembelajaran tentang media pembelajaran dan model pembelajaran yang sama dipilih adalah pendekatan Struktural (PS) jenis stuktur Number-HeadsTogether (NHT) dengan materi pokok bahasan yang berbeda dari siklus 1 yaitu Penyederhanaan Logik Bentuk Kanonik dan Karnough MAP. Model pembelajaran ini digunakan untuk melibatkan mahasiswa dalam menelaah yang tercakup dalam suatu pelajaran dan mengecek pemahaman mereka terhadap isi pelajaran tersebut. Dosen model memilih pendekatan ini struktur NHT ini karena materi pembelajaran memungkinkan mahasiswa untuk berlatih lebih banyak melakukan latihan untuk meningkatkan pemahaman materi dan keaktifan mahasiswa di kelas. 


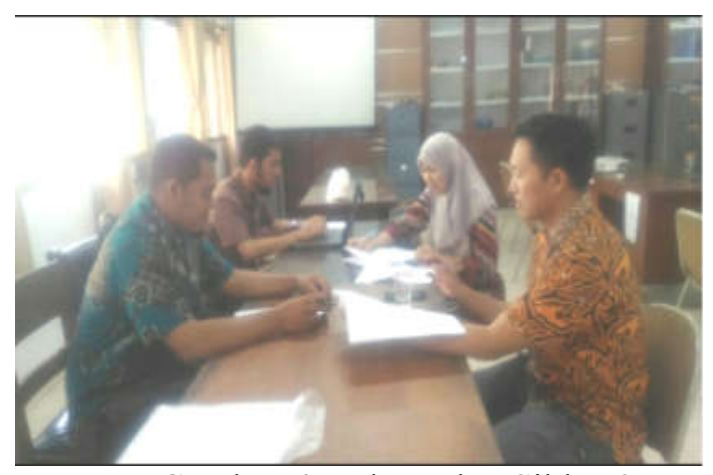

Gambar 6. Tahap Plan Siklus 2

Tahap Do pada siklus ke-2. Tahap ini diamati oleh 4 orang observer. Dosen model memulai perkuliahan dengan memberi salam, dosen model memperkenalkan diri, salah satu mahasiswa memimpin doa, dosen mengecek kehadiran mahasiswa, membahas tugas pada pertemuan sebelumnya secara bersama-sama. Dosen dan mahasiswa mengaitkan kompetensi yang telah dipelajari dan dikembangkan sebelumnya dengan kompetensi yang akan dipelajari, dosen mengimformasikan tujuan pembelajaran, dosen menyampaikan garis besar cakupan materi kegiatan yang akan dilakukan.

Pada kegiatan inti dosen model membagi mahasiswa ke dalam 8 kelompok yang beranggotakan 3-4 orang. Pada setiap kelompok diberi penomoran. Kelompok yang telah dibentuk diberi inisial A-H. Dosen membagikan lembar kerja Mahasiswa (LKM) kepada mahasiswa. Pada skenario pembelajaran terdapat 2 latihan pada lembar LKM dan 1 kuis, dosen mengajukan pertanyaan dengan menampilkan gambar pada slide power point yang ditampilkan. Mahasiswa menyatukan pendapat terhadap jawaban pertanyaan dan menyakinan tiap anggota dalam tim mengetahui jawaban tersebut. Mahasiswa menulis jawaban pada LKM. Dosen memanggil mahasiswa yang nomor tertentu, kemudian mahasiswa yang nomornya sesuai mengacungkan tangan dan menjawab pertanyaan tersebut di depan kelas. Pemberian ice breaking dengan tema menebak warna tulisan membuat mahasiswa antuasias mengikutinya. Selanjutnya reward diberi kepada kelompok yang berhasil menjawab pertanyaan dengan tepat. Aktivitas-aktivitas mahasiswa pada Kegiatan Do di siklus 2 seperti gambar 7 sampai dengan gambar 9 berikut ini.

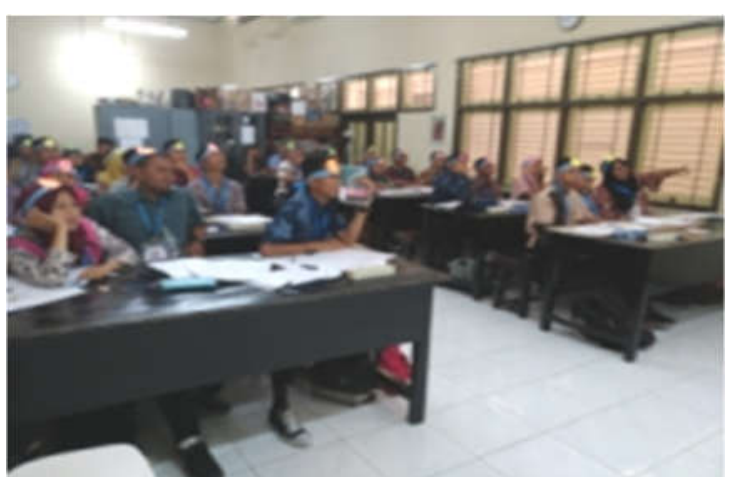

Gambar 7. Kegiatan Do Siklus 2

Pembentukan Kelompok Belajar

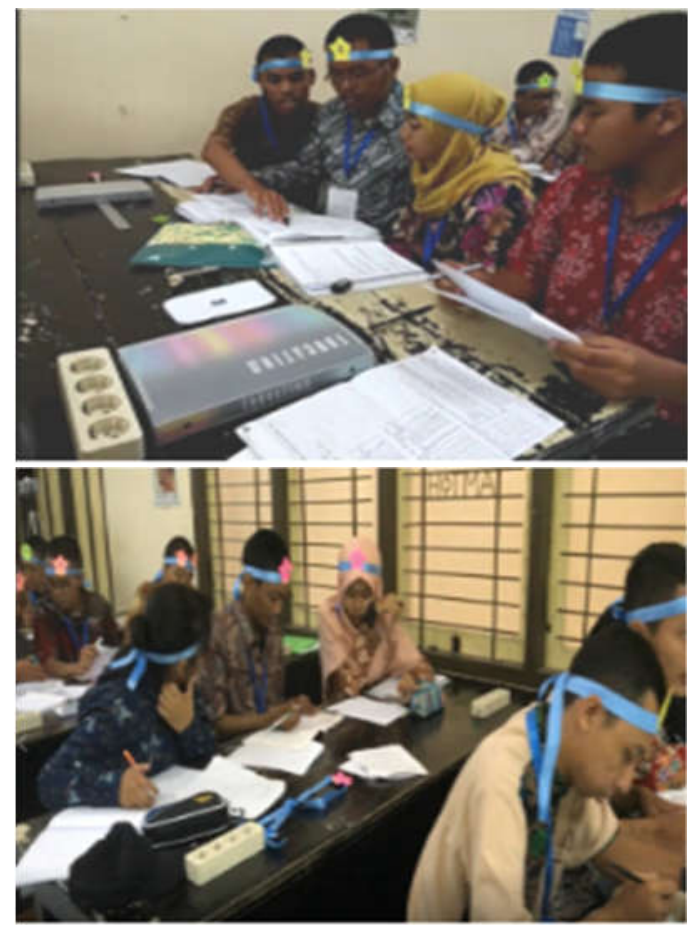

Gambar 8. Kegiatan Do Siklus 2 Mahasiswa Berpikir Bersama dan Menyatukan Pendapat

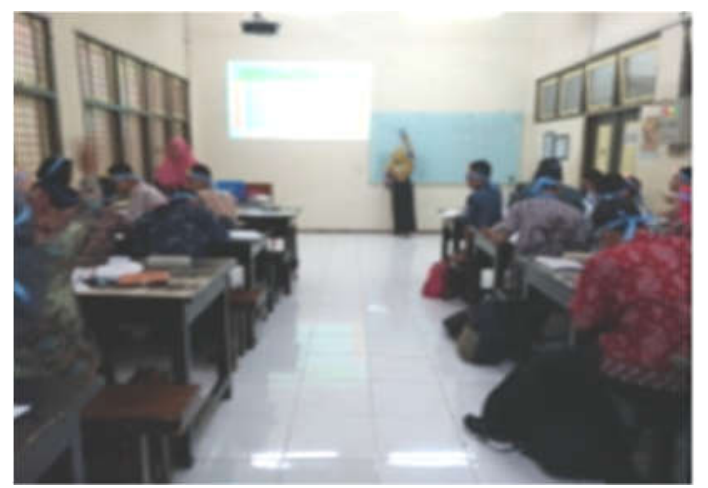

Gambar 9. Kegiatan Do siklus 2 Mahasiswa Maju ke Depan Kelas

Terlihat mahasiswa aktif untuk melaksanakan diskusi, bekerjasama, saling berinteraksi dengan teman sejawatnya, aktif bertanya dan memberikan 
pendapat untuk menyelesaikan latihan-latihan yang diberikan dosen. Dosen model dan mahasiswa bersama-sama menyimpulkan mengenai materi pembelajaran, menyampaikan tugas dari materi yang telah dibahas, mahasiswa mengungkapkan kesan dan manfaat pembelajaran yang telah dilaksanakan, dosen menutup pembelajaran dengan doa bersama dan memberi salam.

Kegiatan see pada siklus ke 2, didapatkan lesson learn yaitu pembelajaran yang menyenangkan memberikan motivasi dan semangat yang tinggi bagi mahasiswa. Lesson learn yang dikemukakan oleh observer yaitu persiapan dosen model sangat baik, arahan terhadap mahasiswa dan pemberian ice breaking mampu mengembalikan fokus mahasiswa dan semangat kembali terutama jam pelajaran mendekati istirahat siang yang sering membuat mahasiswa tidak fokus, mengantuk, dan kurang tertarik, pembagian kelompok heterogen mampu meningkatkan keaktifan mahasiswa dalam belajar, perubahan posisi duduk anggota kelompok dapat mengaktifkan diskusi (interaksi mahasiswa setelah pembentukan kelompok semakin tinggi), pemberian reward mampu menstimulasi mahasiswa untuk aktif, Upaya dosen model lainnya menstimulus mahasiswa agar aktif dan meningkatkan pemahaman mahasiswa dengan memberikan contoh, latihan latihan berkelanjutan berupa Lembar kerja mahasiswa (LKM), menunjuk beberapa mahasiswa yang menjadi perwakilan untuk menjawab/mempresentasikan jawaban di depan kelas. Pemberian kuis mampu meningkatkan keaktifan dan pemahaman mahasiswa dengan waktu yang telah ditetapkan untuk saling berlomba memberikan jawaban yang benar dan yang pertama. Kepekaan dosen model baik dalam meningkatkan fokus dan ketertarikan belajar mahasiswa. Dosen model mencocokkan jawaban mahasiswa dan mengklarifikasi jawaban mahasiswa yang paling tepat. Pembelajaran yang dilakukan dosen model sangat efektif menghemat waktu daalam meningkatkan aktivitas belajar mahasiswa.

Manfaat lesson study menurut para ahli yang dikemukakan oleh [4] bahwa lesson study memiliki beberapa manfaat sebagai berikut. 1) mengurangi keterasingan pendidik (dari komunitasnya), 2) membantu guru untuk mengobservasi dan mengkritisi pembelajarannya 3) memperdalam pemahaman pendidik tentang materi pelajaran, cakupan dan urutan materi dalam kurikulum, 4) membantu pendidik memfokuskan bantuannya pada seluruh aktivitas belajar mahasiswa, 5) menciptakan terjadinya pertukaran pengetahuan tentang pemahaman berpikir dan belajar mahasiswa, 6) meningkatkan kolaborasi pada sesama pendidik.

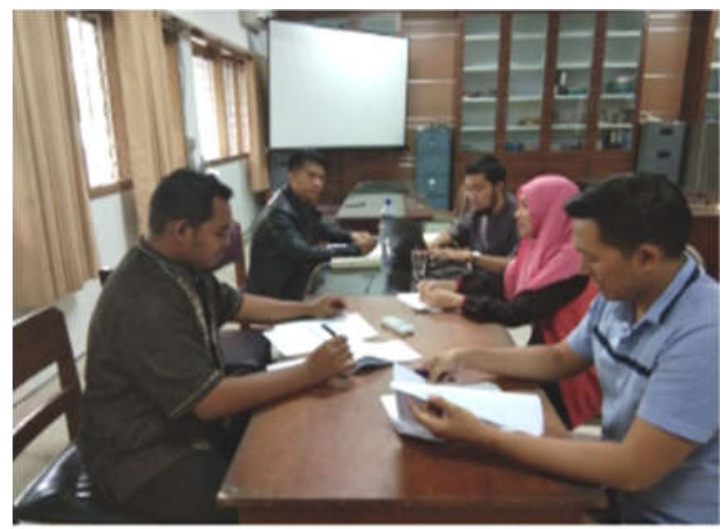

Gambar 10. Kegiatan See siklus 2

Data hasil pelaksanaan Lesson study pada siklus 1 dan 2. ditunjukkan pada gambar 11 dan 12. berikut ini.

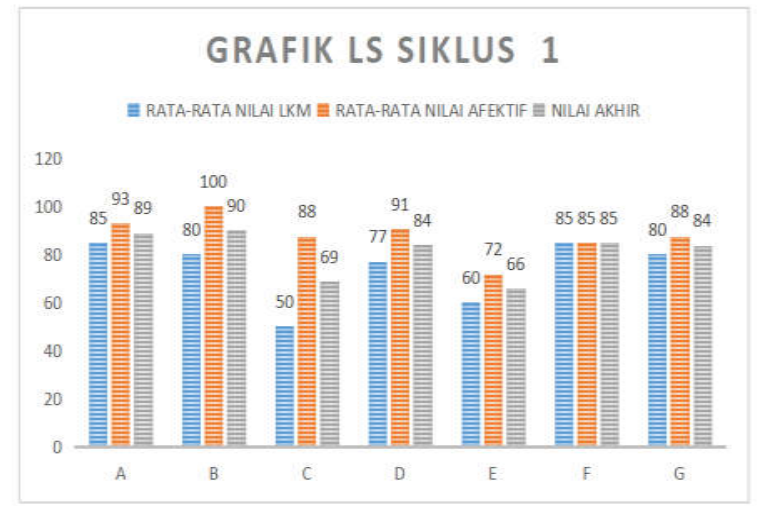

Gambar 11. Grafik LS siklus 1

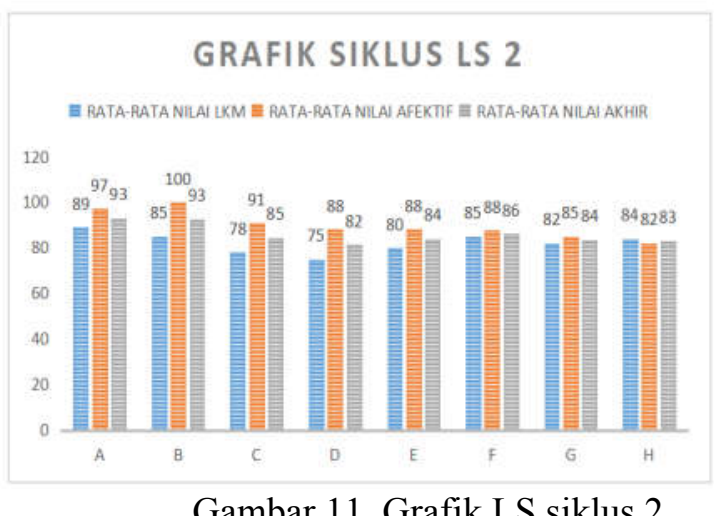

Pernyataan item pada LKM pembelajaran pada siklus 1 dan 2 lesson study meliputi aspek: (1) visual activities: memperhatikan gambar slide power point yang ditampilkan, (2) writing 
activities : membuat tabel kebenaran, menuliskan ekspresi Sum of Product, menyederhanakan ekspresi Aljabar Boolean, menyederhanakan ekspresi dengan kanonik dan karnaugh map (3) drawing activities: menggambarkan rangkaian gerbang logika dari persamaan Aljabar Boolean.

Pernyataan item pada lembar observasi pembelajaran pada siklus 1 dan 2 lesson study yaitu: (1) pengetahuan awal mahasiswa, (2) mahasiswa yang tidak dapat mengikuti kegiatan pembelajaran, (3) interaksi antar mahasiswa dalam kelompok: bertanya, kerjasama tim dan mendengarkan, pengambilan keputusan, (4) interaksi mahasiswa antar kelompok, (5) interaksi mahasiswa dengan media/sumber belajar, (6) interaksi mahasiswa dengan dosen (7) interaksi mahasiswa dengan lingkungan.

\section{KESIMPULAN}

Pembelajaran yang dilaksanakan melalui lesson study memberikan manfaat bagi peningkatan aktivitas mahasiswa meliputi pemahaman materi pembelajaran, tingkat kefokusan mahasiswa, kerjasama dalam tim, aktif berinteraksi mengemukakan pendapat, berpikir bersama, pengambilan keputusan dalam pembelajaran dasar teknik digital.

Pembentukan komunitas belajar yang dapat membantu kelancaran dan peningkatan aktivitas mahasiswa dalam pembelajaran sangat penting dilakukan secara kolaborasi. Menemukan pendekatan-pendekatan yang sesuai untuk diterapkan pada setiap materi belajar. Pada tahap perancangan skenario pembelajaran harus menyiapkan RPP, media, metode pembelajaran, yang terkait dengan pembelajaran abad 21 perlu dipersiapkan dengan baik supaya pembelajaran dapat berjalan dengan lancar dan menarik. Dapat juag ditambah dengan unsur ice breaking dan pemberian reward. Hal tersebut dapat meningkatkan antusias dan tingkat kefokusan mahasiswa pada proses pembelajaran. Lesson learn setelah melakukan siklus-siklus pada Lesson study dapat dimanfaatkan oleh pendidik (dosen) sebagai perbaikan dari pembelajaran yang dilakukan.

\section{UCAPAN TERIMA KASIH}

Terima kasih penulis ucapkan kepada Universitas Negeri Padang dan Kemenristek Dikti telah mendukung kelancaran kegiatan Program Magang Dosen Tahun 2018.

\section{DAFTAR PUSTAKa}

[1] S. Zubaidah, "Keterampilan abad ke-21: keterampilan yang diajarkan melalui pembelajaran," in "Isu-isu Strategis Pembelajaran MIPA Abad 21," 2016, no. December 2016, pp. 1-17.

[2] A. R. Saavedra et al., "21.Century Skills," no. April, pp. 1-35, 2012.

[3] W. Wibawanto, Desain dan Pemrograman Multimedia Pembelajaran Interaktif, no. January. 2017.

[4] Suardi, "Aktifitas Mahasiswa dalam Lesson Study pada Pembelajaran English Learning Media," in Prosiding Seminar Nasional, 2016, vol. 02, pp. 587-598.

[5] H. K. E. . Moro et al., "Penerapan Indonesia Lesson Study Untuk Meningkatkan Aktifitas Penerapan Indonesia Lesson Study," no. August, 2016.

[6] R. D. Kurnia, E. L. Ruskan, and A. Ibrahim, "Pengembangan Model Pembelajaran Berbasis Cooperative Learning dalam Meningkatkan Motivasi Belajar Mahasiswa dan Peningkatan Mutu Lulusan Alumni Fasilkom Unsri Berbasis E-Learning (studi kasus: matakuliah pemrograman web)," $J$. Sist. Inf., vol. 6, no. 1, pp. 645-654, 2014.

[7] M. Chamdani, K. C. Suryandari, and I. Suyanto, "Pengembangan Model Research Based Learning Dengan Pendekatan Scientific Melalui Lesson Study Dalam Pembelajaran IPS Di Sekolah Dasar Tahun," in "Inovasi Pembelajaran untuk Pendidikan Berkemajuan," 2015, no. November, pp. 673-682.

[8] B. Supriyanto, "Penerapan Pembelajaran Lesson Study Berbasis Kreatif Dan Produktif Pada Matakuliah Teknik Perkerasan Jalan Guna Meningkatkan Hasil Belajar Mahasiswa Prodi S1 Pendidikan Teknik Bangunan," Teknol. dan Kejuru., vol. 36, no. Pebruari, pp. 29-40, 2013.

[9] F. A. Tadanugi, "JURNAL KIP - Vol. IV. No. 2, Juli 2015 - Oktober 2015," vol. IV, 
no. 2, pp. 927-932, 2015.

[10] H. I. Oktaviani and A. Supriyanto, "Profesionalitas Dosen Muda Universitas Negeri Malang Dalam Pelaksanaan Pembelajaran Melalui Lesson Study," edcomtech, vol. 3, no. Vol 1, pp. 39-46, 2018.

[11] S. A. Dewanto, Slamet, B. Wulandari, and P. W. Pranoto, "IMPLEMANTASI LESSON STUDY UNTUK MENINGKATKAN KUALITAS," $J$. Electron. Informatics, Vocat. Educ., vol. 1, no. Mei 2016, pp. 97-103, 2016.

[12] J. Anton, K. Kusno, and E. Fitrianto, “Aktivitas Kerjasama Mahasiswa Dalam Pembelajaran Kooperatif Mata Kuliah Dasar Proses Pembelajaran Matematika Melalui," in Seminar Nasional Matematika dan Pendidikan Matematika FMIPA UNY Yogyakarta, 2013, no. November, pp. 978979.
[13] A. Fanani, "Ice Breaking Dalam Proses Belajar Mengajar," J. Buana Pendidik., vol. Vol. VI, no. Oktober 2010, pp. 67-70, 2010.

[14] S. Antonius, T. H. Jensen, C. Haines, and M. Niss, "Chapter 3.4.3 CLASSROOM ACTIVITIES AND THE TEACHER," in Modelling and Aplications in Mathematics Education, Springer, Boston, MA, 2007, pp. 295-308.

\section{Biodata Penulis}

Ilmiyati Rahmy Jasril, Sarjana Pendidikan di Jurusan Teknik Elektronika FT UNP 2011. Tahun 2013 memperoleh gelar Magister Pendidikan di Prodi Pendidikan Teknologi dan Kejuruan Program Pascasarjana FT UNP dengan bidang konsentrasi Pendidikan Teknik Elekronika. Staf pengajar di jurusan Teknik Elektronika FT UNP sejak tahun 2015- sekarang. 